\title{
Characterization, purification and phylogenetic analysis of a cytolysin from the sea anemone Heteractis magnifica of the Indian Ocean
}

\section{Karthikayalu S (1, 2, 3), Rama V (2), Kirubagaran R (1), Venkatesan R (1)}

(1) National Institute of Ocean Technology, Chennai, Tamil Nadu, India; (2) Department of Industrial Biotechnology, Dr. M.G.R. University, Maduravoyal, Chennai, Tamil Nadu, India; (3) AxioGen Biotech Private Limited, Pondicherry, India.

\begin{abstract}
It is well established that sea anemones comprise a rich source of cytolytic toxins. The present study reports the isolation and characterization of a cytolysin obtained from the sea anemone Heteractis magnifica collected in the Andaman Islands of the Indian Ocean. The crude extract was screened for hemolytic activity by a blood agar plate method and a 6-mm zone of clearance was observed after incubation. The hemolytic property of the crude extract, tested by the microtiter plate method, revealed positive results at concentrations as low as $120 \mathrm{ng} / \mathrm{mL}$. Furthermore, it was favored by alkaline $\mathrm{pH}$ and was stable up to $60^{\circ} \mathrm{C}$. On the other hand, the hemolytic effect was abolished by the addition of human serum. Purification steps involved ammonium sulfate precipitation and subsequent desalting by dialysis, followed by anion- and cation-exchange chromatographies. The purified fractions displayed the presence of a $19-\mathrm{kDa}$ cytolysin when analyzed by SDSPAGE. The conserved region of the cytolysin (with $303 \mathrm{bp}$ ) was amplified by RT-PCR and was sequenced. The sequence showed maximum homology $(97 \%)$ with the already reported cytolysins from other sea anemone species.
\end{abstract}

KEY WORDS: Heteractis magnifica, marine toxin, hemolysin, cytolysin.

CONFLICTS OF INTEREST: There is no conflict.

\section{CORRESPONDENCE TO:}

KARTHIKAYALU SUBBRAYALU, Department of Industrial Biotechnology, Dr. M.G.R.

Educational and Research Institute, Dr. M.G.R. University, Maduraoyal, Chennai 600095, India. Phone: +91 44 23782176. Fax: +91 44 23783165. Email: karthikayalu@gmail.com. 


\section{INTRODUCTION}

The cnidarians comprise species of mostly marine aquatic invertebrates that constitute the phylum Cnidaria represented by sea anemones, corals, sea fans, sea pens, jellyfish and zooanthids, which are known to secrete a variety of cytolytic toxins mainly for defensive purposes (1-5). Four major groups of these cytolysins are found in cnidarians $(5,6)$. Among them, the 19-kDa pore-forming cytolysins are the most predominant (5-15). In previous studies, the sea anemone Heteractis magnifica was subjected to the analysis of different cytolysins including magnificalysins $\mathrm{Hmg} \mathrm{I}, \mathrm{Hmg}$ II and Hmg III (14-18). However, Hmg III is the most potent and active cytolysin, whose molecular mass has been determined as $19 \mathrm{kDa}$ (14-15). The N-terminal amino acid sequences of Hmg III also exhibited homology with other sea anemone hemolysins such as equinatoxins from Actinia equina, tenebrosin- $C$ from Actinia tenebrosa and cytolysin III from Stichodactyla helianthus (19-21).

Besides being known as a pore-forming cytolysin, Hmg III has not been further investigated on its physiological characteristics regarding the cytolytic activity. Hence, the present study has been undertaken on the isolation, physiological characterization and purification of the cytolysin Hmg III from the sea anemone Heteractis magnifica employing a human erythrocyte model. Furthermore, the sequence verification has also been performed on this Indian sea anemone species and compared with a Singaporean species of which the sequence has been already known. The sequence comparison among cytolysins of other cnidarians - such as Stichodactyla helianthus, Heteractis crispa, Actinia equina and Oulactis orientalis has also been performed by a phylogenetic analysis for establishing a genetic relationship.

\section{MATERIALS AND METHODS}

\section{Collection of the Sea Anemone Heteractis magnifica}

The sea anemone Heteractis magnifica - identified by Fautin and Allen (22) - was collected from Andaman Islands, India, at a depth of $5 \mathrm{~m}$ by scuba diving.

\section{Preparation of the Toxin}

In the laboratory, the live animal was induced through osmotic thermal stress to eject the epithelial mucus that contains the toxins (8). The cnidarian toxins are stored in the cnida, a capsule within specialized cells that contains a barbed, threadlike tube 
that delivers a paralyzing sting when propelled into attackers and prey. Approximately $2 \mathrm{~kg}$ of anemone was added to $1 \mathrm{~L}$ of warm distilled water (40 to $45^{\circ} \mathrm{C}$ ) for 15 minutes and subject to intermittent stirring to minimize tissue damage. After 15 minutes, the anemone was removed and the solution was filtered. The filtrate was stored in $100-\mathrm{mL}$ aliquots in liquid nitrogen for transportation. Subsequently, the extract was removed from the nitrogen and stored at $-70^{\circ} \mathrm{C}$ until analysis. When required, the aliquots were thawed, concentrated by lyophilization and reconstituted in phosphate buffered saline at $\mathrm{pH} 7.4$.

\section{Protein Assay}

Protein concentration was determined by the Lowry et al. method using bovine serum albumin (BSA) as standard (23). The protein concentration during purification studies was measured from the absorbance at $280 \mathrm{~nm}$. One hundred microliters of purified fractions were read at $280 \mathrm{~nm}$ using SpectraMax® microplate reader (Molecular Devices, USA).

\section{Hemolytic Activity on Human Blood Agar Plate}

Human blood agar plate was prepared by adding $5 \mathrm{~mL}$ of human blood to $95 \mathrm{~mL}$ of sterile nutrient agar and pouring the mixture immediately on petri plates. After solidification, wells were cut on the agar plate using a corkscrew borer $(8 \mathrm{~mm}$ diameter). Wells were loaded with $50 \mu \mathrm{L}(1 \mathrm{mg} / \mathrm{mL})$ of protein samples. The plates were observed for hemolysis after overnight incubation at room temperature.

\section{Hemolytic Assay}

Hemolytic activity of the toxin was measured quantitatively in terms of attenuance on human red blood cells at room temperature using a microplate reader. Freshly collected human blood with heparin was centrifuged to remove the buffy coat. Afterward, the obtained erythrocytes (RBC) were washed three times in $0.85 \%$ saline and stored at $4^{\circ} \mathrm{C}$. Toxins at determined concentrations were added in the first well to erythrocyte buffer (140 mM NaCl, $10 \mathrm{mM}$ Tris- $\mathrm{HCl}, \mathrm{pH}$ 7.4) and then subjected to two-fold serial dilution. RBC (100 $\left.\mu \mathrm{L} ; D_{630}=0.5\right)$ in erythrocyte buffer were added to the toxins, and hemolysis was monitored by measuring attenuance at $630 \mathrm{~nm}$ for 20 minutes at room temperature. The final volume in all wells was $200 \mu \mathrm{L}$. The 
percentage of hemolysis was determined at the end of the assay using the following equation of Maček et al. (24):

$$
\text { Hemolysis }(\%)=\left(D_{\max }-D_{\text {obs }}\right) /\left(D_{\max }-D_{\min }\right) \times 100
$$

in which $D_{\text {obs }}$ is the measured attenuance in the well after 20 minutes and $D_{\max }$ is the maximal attenuance by distilled water and $D_{\min }$ is the minimal attenuance by erythrocyte buffer.

\section{Characterization of the Hemolytic Extract}

The crude hemolytic extract was characterized with respect to thermal and $\mathrm{pH}$ stability, freeze-thaw stability and treatment with human serum.

\section{Effect of temperature and freeze-thaw process}

In order to study the stability of the extract under different temperatures, it was exposed to different heat treatments: $25^{\circ} \mathrm{C}$ (room temperature), $60^{\circ} \mathrm{C}$ for one hour, $80^{\circ} \mathrm{C}$ for one hour, $100^{\circ} \mathrm{C}$ for one hour and $121^{\circ} \mathrm{C}$ and 15 psi by autoclaving for 15 minutes. The extract was also frozen at $-80^{\circ} \mathrm{C}$ and then quickly thawed to $37^{\circ} \mathrm{C}$. The freeze-thaw procedure was repeated three times and the hemolytic activity was assessed.

\section{Effect of pH}

The buffer $\mathrm{pH}$ of the extract was 9 and was adjusted to $3,4,5,6,7$ and 8 with hydrochloric acid $(\mathrm{HCl})$, then, incubated for one hour at room temperature and assayed.

\section{Effect of human serum}

Human serum was added to the extract at a final concentration of $1 \%$ and incubated at room temperature for one hour. The mixtures were assessed for hemolytic activity against human RBC, with serum-free extract as control.

\section{Ammonium Sulfate Precipitation}

The crude extract was treated with ammonium sulfate (Himedia Laboratories, India) to $20,40,60,80$ and $100 \%$ saturation according to the Rosenberg table (25). The 
mixtures were stirred for 30 minutes at $4^{\circ} \mathrm{C}$ and centrifuged afterward at $10000 \times \mathrm{g}$ for ten minutes at $4^{\circ} \mathrm{C}$. The precipitates were resuspended in $10 \mathrm{mM}$ sodium phosphate buffer ( $\mathrm{pH} \mathrm{7.2)} \mathrm{and} \mathrm{desalted} \mathrm{in} \mathrm{a} \mathrm{dialyzing} \mathrm{tube} \mathrm{with} \mathrm{a} \mathrm{cutoff} \mathrm{of} 12$ to 14 kDa (Himedia Laboratories, India) against $10 \mathrm{mM}$ sodium phosphate buffer at pH 7.2.

\section{Sodium Dodecyl Sulfate Polyacrylamide Gel Electrophoresis (SDS- PAGE)}

Protein samples were analyzed by SDS-PAGE using $5 \%$ stacking gel and $12 \%$ resolving gels (26). Samples were denatured by boiling in loading buffer containing SDS and $\beta$-mercaptoethanol before they were placed on the gel. Thirty micrograms of crude protein and $10 \mu \mathrm{g}$ of purified fractions were placed on the gel and underwent electrophoresis. Following electrophoresis at $15 \mathrm{~mA}$ for four hours, gels were stained with Coomassie brilliant blue R-250 (Himedia Laboratories, India) and destained in a solution of $50 \%(\mathrm{v} / \mathrm{v})$ methanol and $10 \%(\mathrm{v} / \mathrm{v})$ acetic acid.

\section{Purification of Hemolytic Proteins by lon-Exchange Chromatography}

The dialyzed fractions were purified by ion-exchange chromatography. Anionexchange chromatography was performed using DEAE-cellulose column $(1 \times 5 \mathrm{~cm})$ at a flow rate of $1 \mathrm{~mL} /$ minute (25). The column-stabilizing buffer was $10 \mathrm{mM}$ sodium phosphate buffer, $\mathrm{pH}$ 7.0. Two-milliliter $(10 \mathrm{mg} / \mathrm{mL})$ of the crude protein extract in stabilizing buffer was placed on the column. Elution of the bound proteins was performed using a linear gradient of sodium chloride $(0.1 \mathrm{M}, 0.25 \mathrm{M}, 0.5 \mathrm{M}, 1 \mathrm{M}$ and $1.25 \mathrm{M})$. Protein concentrations of the collected fractions were measured by absorbance at $280 \mathrm{~nm}$ using a microplate reader and fractions showing hemolytic activity were pooled together, lyophilized and dialyzed against $10 \mathrm{mM}$ phosphate buffer overnight at $4^{\circ} \mathrm{C}$. The dialyzed fractions were subjected to cation-exchange chromatography using CM-cellulose column and a similar method previously described in this study.

\section{Isolation of RNA}

Total RNA was isolated from the tentacles of the sea anemone $H$. magnifica using TRIzol $($ reagent according to the manufacturer's protocol (ABgene, UK). The quality of the RNA preparation was determined by electrophoresis in agarose gel (1.2\%) and the RNA was employed for reverse transcription reaction. 


\section{Reverse Transcription Polymerase Chain Reaction (RT-PCR)}

One microgram of $H$. magnifica RNA was used in the RT-PCR performed with Reverse-iT® One-step RT-PCR kit (ABgene, UK) in a total reaction volume of $20 \mu \mathrm{L}$. Gene-specific primers (HMg2F 5P-ATTGATGGTGCAAGTCTGGG-3P, HMg2R 5PGTTGCTGTACCAGTTATAGTC-3P) were utilized for the amplification reaction. Primer sequences were obtained according to Wang et. al (14). Other components of the RT-PCR reaction were $2 x$ RT-PCR master mix (Thermoprime plus DNA polymerase, reaction buffer, $0.2 \mathrm{mM}$ dNTP mix and $1.5 \mathrm{mM} \mathrm{MgCl}_{2}-$ ABgene, UK) and $50 \mathrm{U} / \mu \mathrm{L}$ of Reverse-iT尺 RTase blend (ABgene, UK). The mixture was incubated for one hour at $42^{\circ} \mathrm{C}$ and inactivated by heating at $95^{\circ} \mathrm{C}$ for five minutes. PCR was performed by denaturation at $95^{\circ} \mathrm{C}$ for 20 seconds, annealing at $55^{\circ} \mathrm{C}$ for 30 seconds, extension at $72^{\circ} \mathrm{C}$ for 30 seconds and final extension at $72^{\circ} \mathrm{C}$ for five minutes. The PCR product was electrophoresed on $1.2 \%$ agarose gel. The PCR band was excised from the agarose gel and eluted and purified using a gel elution kit (Eppendorf, Germany) according to the manufacturer's protocol. The purified PCR product was sequenced.

\section{RESULTS}

\section{Hemolytic Assay}

The hemolytic activity of the crude extract is shown in the Figure 1. A 6-mm diameter clear zone of lysis was observed around the wells in human blood agar plates when $50 \mathrm{mg}$ of crude extract was added after incubation (Figure 1). The hemolysis induced by hemolysins in red blood cells suspension was concentration-dependent (Figure 2). The crude extract revealed $50 \%$ hemolysis at a concentration of $\sim 120 \mathrm{ng} / \mathrm{mL}$ by microtiter plate assay (Figure 2).

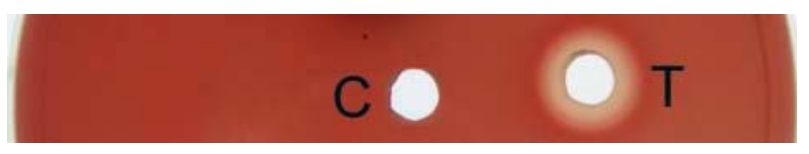

Figure 1. Hemolytic activity of the crude toxin on blood agar plate.

C: control (PBS buffer, pH-7.4); T: crude toxin. 


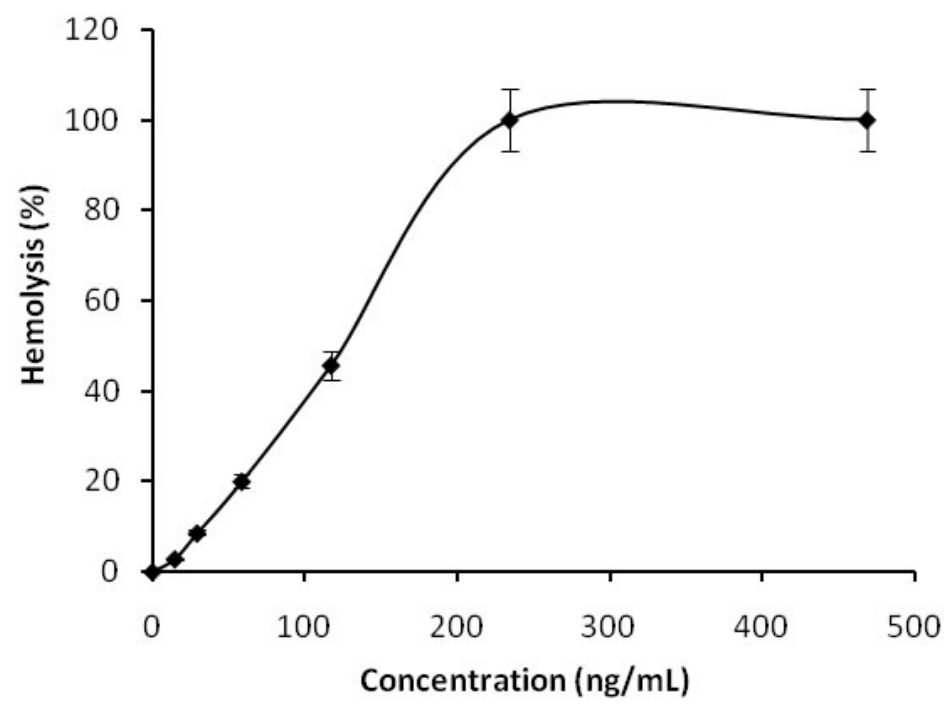

Figure 2. Titration of hemolytic activity. Hemolysis was measured turbidimetrically at room temperature using a microplate reader. The hemolysis percentage was calculated as described in "Materials and Methods". Data points shown are means of three independent experiments (triplicates).

\section{Physiological Properties}

Hemolytic activity peaked at room temperature $\left(25^{\circ} \mathrm{C}\right)$ and was partially reduced at $60^{\circ} \mathrm{C}$. No activity was observed when the extract was subject to more than $80^{\circ} \mathrm{C}$ for one hour (Figure $3-A$ ). Frequent freeze-thaw processes of the stored samples at $80^{\circ} \mathrm{C}$ affected considerably the hemolytic activity (Figure $3-\mathrm{A}$ ). The pl of this toxin ranges from 9.0 to 10.0. Therefore, its activity in in vitro conditions has also been assumed to occur at this high $\mathrm{pH}$ level. Hence, hemolysis was favored in an alkaline $\mathrm{pH}$ (Figure $3-\mathrm{B}$ ) whereas activity was reduced in acidic medium. On the contrary, addition of $1 \%$ human serum to the extract resulted in neutralization of the hemolytic activity (Figure $3-C$ ). 


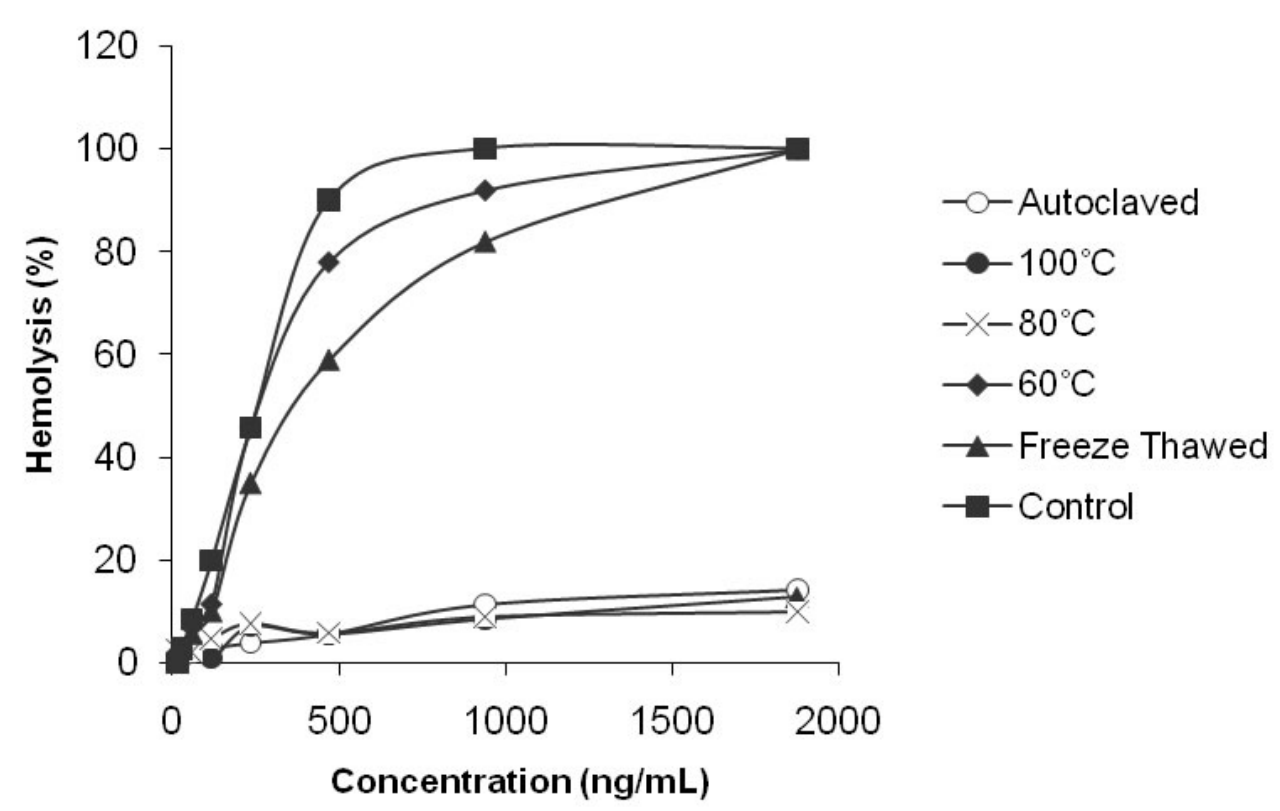

A

B

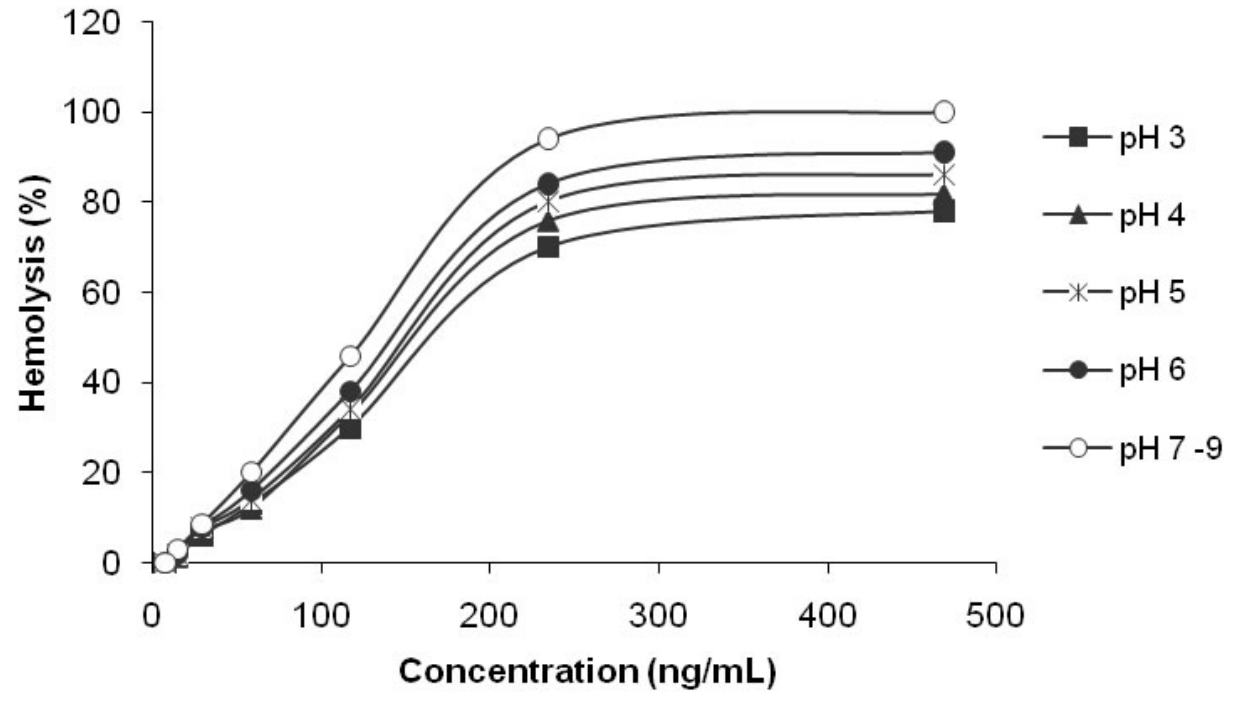




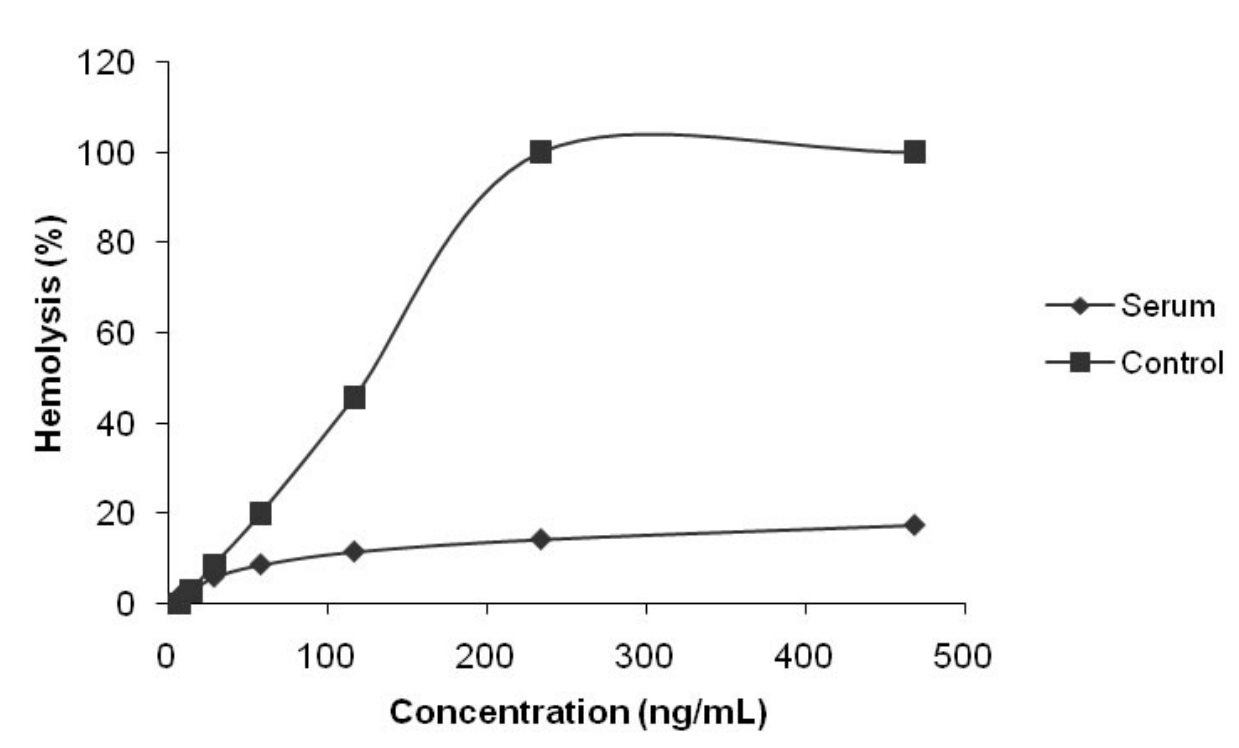

Figure 3. Physiological characteristics of the hemolytic fraction. (A) The effects of temperature, $(\mathbf{B}) \mathrm{pH}$ and $(\mathbf{C})$ serum on the toxin hemolytic activity. The toxin showed maximum activity at room temperature and in alkaline $\mathrm{pH}$. The hemolytic activity was neutralized after addition of human serum (C). Data points shown are means of three independent experiments (triplicates).

\section{Precipitation of Hemolytic Toxin}

Table 1 shows the relative distribution of the hemolytic activity of $H$. magnifica crude extract, precipitated by ammonium sulfate. Crude extract proteins were precipitated in $20 \%, 40 \%, 60 \%, 80 \%$ and $100 \%$ fractions. All the fractions obtained during salting out process showed hemolytic activity, which indicates that the toxin was precipitated in all fractions (Table 1). However, proteins separated by 60 to $80 \%$ ammonium sulfate precipitation were found to be more active. SDS-PAGE analysis of ammonium sulfate precipitated fractions possessing cytolytic activity revealed the presence of a protein band with a molecular weight of $19 \mathrm{kDa}$ (Figure 4). 
Table 1. Hemolytic activity of different ammonium sulfate fractions

\begin{tabular}{c|c}
\hline Ammonium sulfate & $\begin{array}{c}\text { Concentrations at which } 50 \% \text { hemolysis was } \\
\text { observed }(\mathbf{n g} / \mathbf{m L})\end{array}$ \\
\hline $20 \%$ & 625 \\
\hline $40 \%$ & 312.5 \\
\hline $60 \%$ & 78.0 \\
\hline $80 \%$ & 39.1 \\
\hline $100 \%$ & 78.0 \\
\hline
\end{tabular}

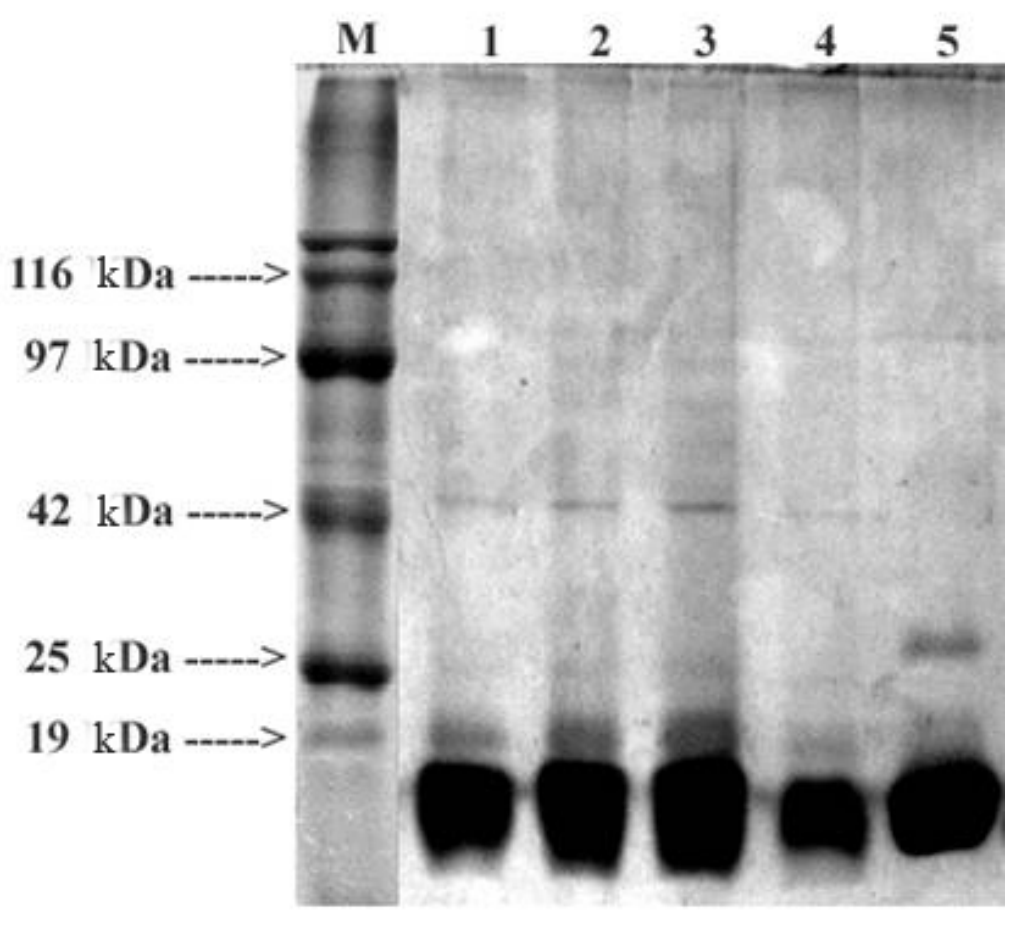

Figure 4. SDS-PAGE analysis of ammonium sulfate fractions. M: marker, lane 1: $100 \%$ ammonium sulfate fraction, lane 2: $80 \%$ ammonium sulfate fraction, lane 3 : 60\% ammonium sulfate fraction, lane 4: 40\% ammonium sulfate fraction, and lane 5: $20 \%$ ammonium sulfate fraction. The 19-kDa hemolytic toxin was precipitated in all fractions but the quantity and activity peaked only in particular fractions (60 to $80 \%$ ).

\section{Toxin Purification by lon-Exchange Chromatography}

The fractionation of the ammonium sulfate precipitated crude extract of $H$. magnifica is shown in Figure $5-A$, after purification by ion-exchange chromatography. Six major peaks, called $A, B, C, D, E$ and $F$, were obtained by DEAE-cellulose column chromatography. Peak $A$ fractions were found to exhibit hemolytic activity. These 
fractions were pooled, lyophilized and dialyzed against $10 \mathrm{mM}$ phosphate buffer overnight at $4^{\circ} \mathrm{C}$. Dialyzed fractions were lyophilized and purified by carboxymethylcellulose $(\mathrm{CM})$ cation-exchange chromatography. Subsequently, six major peaks called A1, A2, A3, A4, A5 and A6 - were obtained by CM-cellulose column (Figure 5 - B) and the fractions under peak $A 6$ showed hemolytic activity. Then, fractions corresponding to peak A6 were pooled together, lyophilized and analyzed by SDSPAGE. 


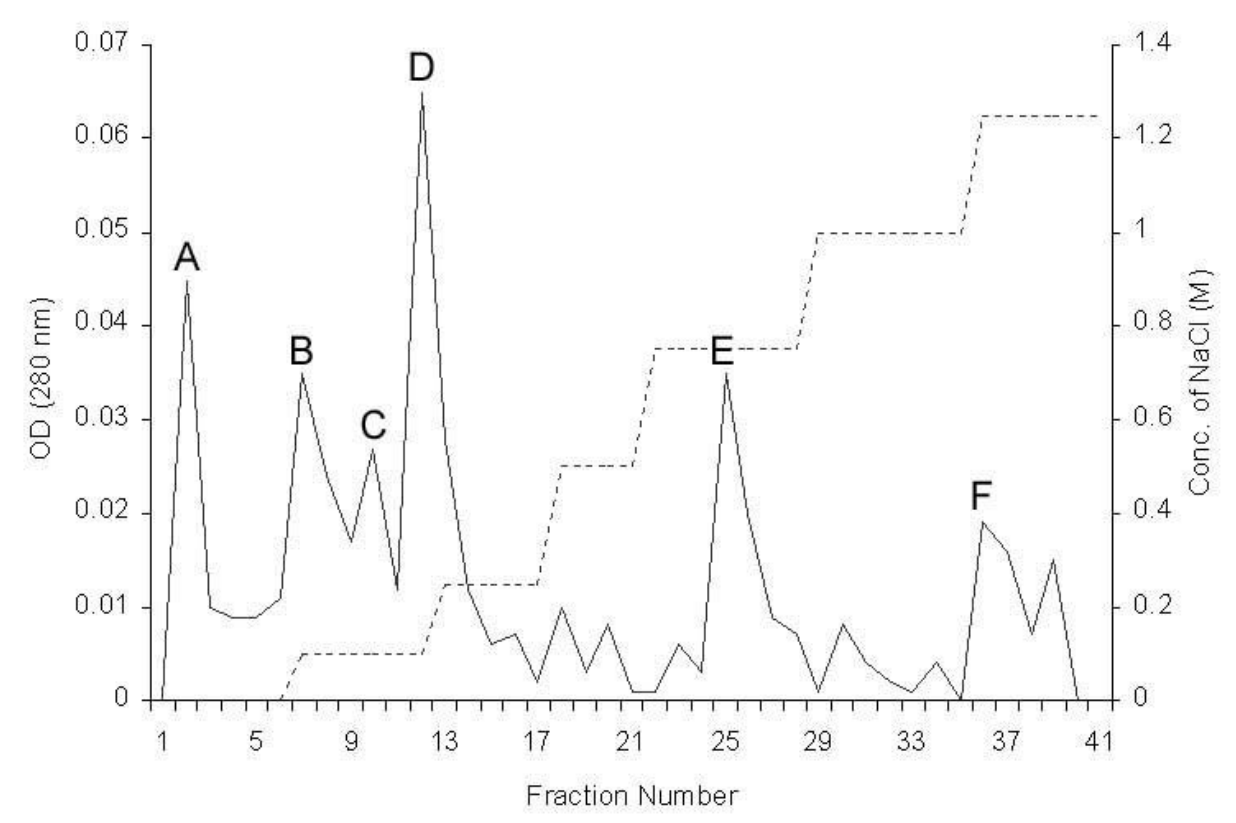

\section{Cation-exchange chromatography}

B

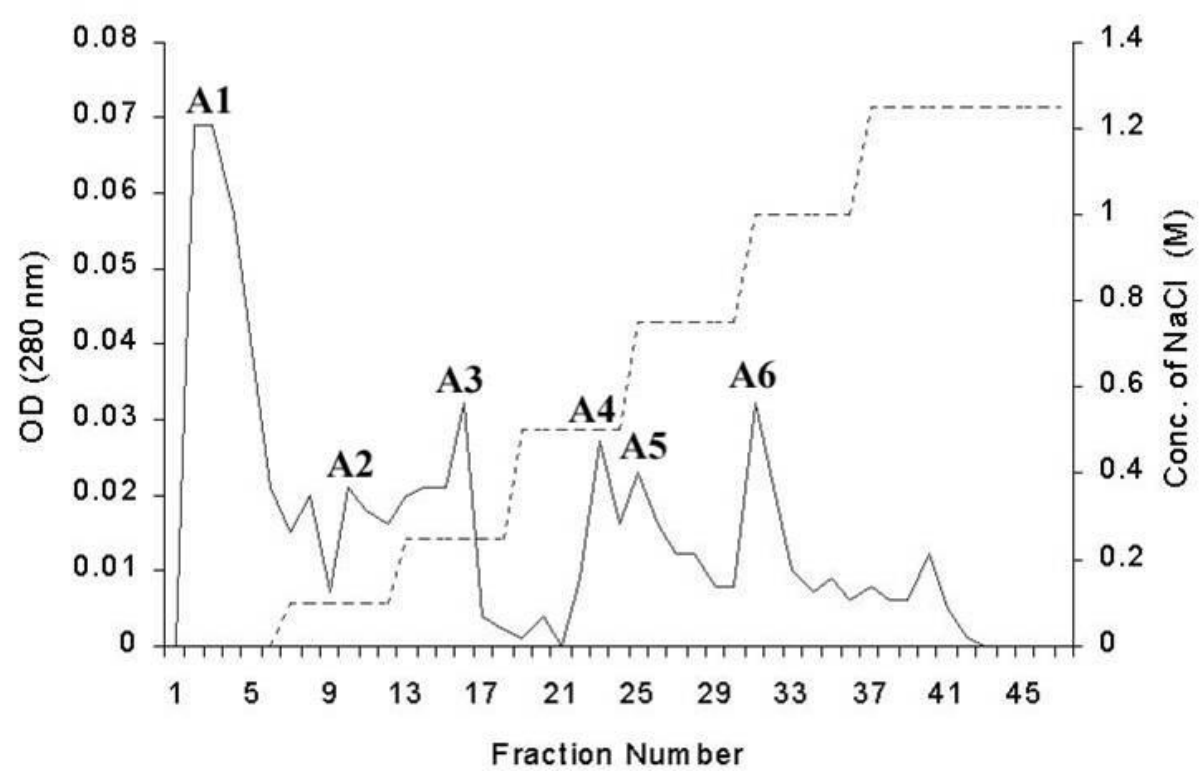

Figure 5. Purification of the hemolytic toxin by ion-exchange chromatography. (A) Heteractis magnifica crude protein, dissolved in $10 \mathrm{mM}$ sodium phosphate buffer $(\mathrm{pH}$ 7.0), was fractionated by DEAE-cellulose anion-exchange chromatography and fractions under peak $A$, showed hemolytic activity. (B) Peak $A$ fractions obtained by anion-exchange chromatography were pooled and fractionated by CM-cellulose cation-exchange chromatography. After removal of the unbound components, a linear salt gradient $(0-1.25 \mathrm{M} \mathrm{NaCl}$ in sodium phosphate buffer, indicated by the dashed line) was added. Fractions from peak A6 showed hemolytic activity. 


\section{SDS-PAGE}

SDS-PAGE analysis of the active fractions revealed two bands of approximately 14 and 19-20 kDa respectively (Figure 6). The result reveals the presence of the $19 \mathrm{kDa}$ pore-forming cytolysin in the purified fractions.

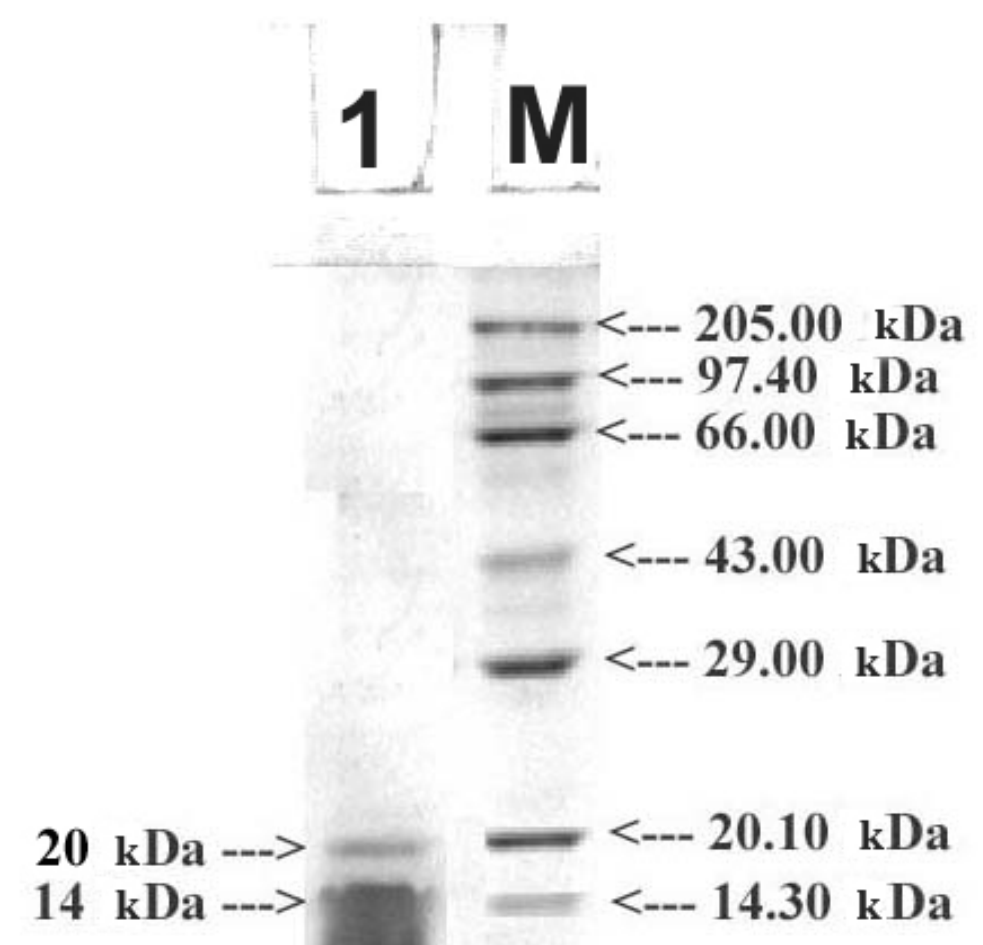

Figure 6. SDS-PAGE analysis of purified fractions.

M: standard protein molecular weight marker. Lane 1: pooled active fractions from the cationexchange chromatography.

\section{RT-PCR}

One hundred micrograms of RNA were extracted from $100 \mathrm{mg}$ of tissue. One microgram of RNA was reverse-transcribed and amplified by RT-PCR. Using PCR primers, HMg2F and HMg2R, a 303 bp PCR product coding for the conserved region of the cytolysin was obtained (Figure 7) and purified. The purified PCR product was sequenced (accession n. AB254368) and analyzed by BLASTn (Figure 8), BLASTx (Figure 9) and Clustal W (Figure 10). 


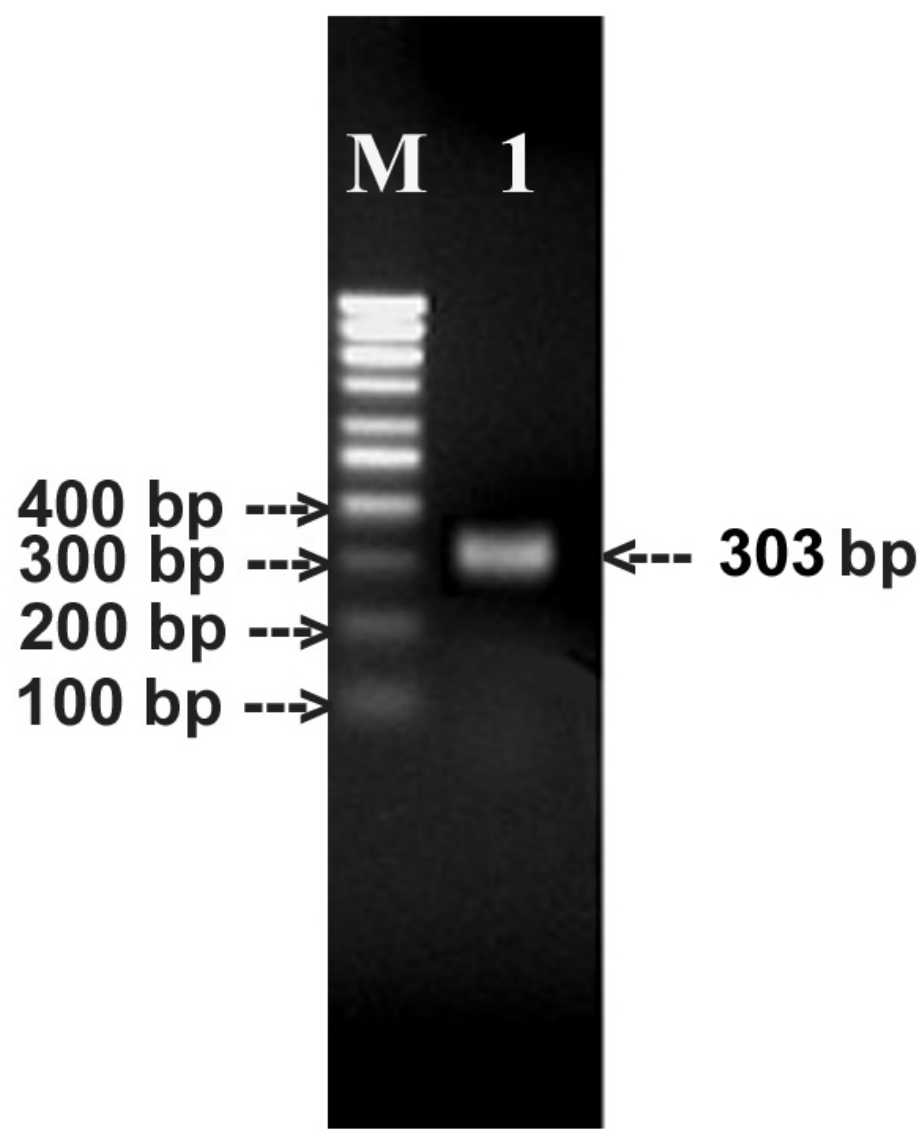

Figure 7. Amplification of the conserved region of the cytolysin gene by RT-PCR. M: 100 bp DNA ladder; lane 1: 303 bp amplified product code for the conserved region of Hmg III.
A 18 AAGTGCTCGGAGACT TGGTAMAGTGTCTCGGAMGATGCTGTCGGTGTCGACAMCGAGT 111111111111111111111111111111111111111111111111111111111111 111111111111111111111111111111111111111111111111111111

Figure 8. Comparison of nucleotide sequences of the Heteractis magnifica cytolysin from (A) Indian and (B) Singaporean waters. Sequence comparison showed changes in seven positions $(273,315,354,377,441,433$ and 456$)$. 


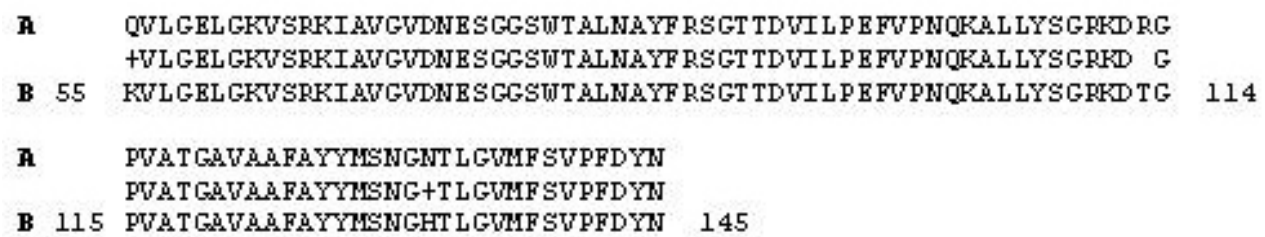

Figure 9. Comparison of deduced amino acid sequences of the Heteractis magnifica cytolysin from (A) Indian and (B) Singaporean waters revealed variation in three amino acids (glutamine is replaced by lysine in $55^{\text {th }}$ position, arginine by threonine in $113^{\text {th }}$ position and asparagine by histidine in $132^{\text {nd }}$ position).

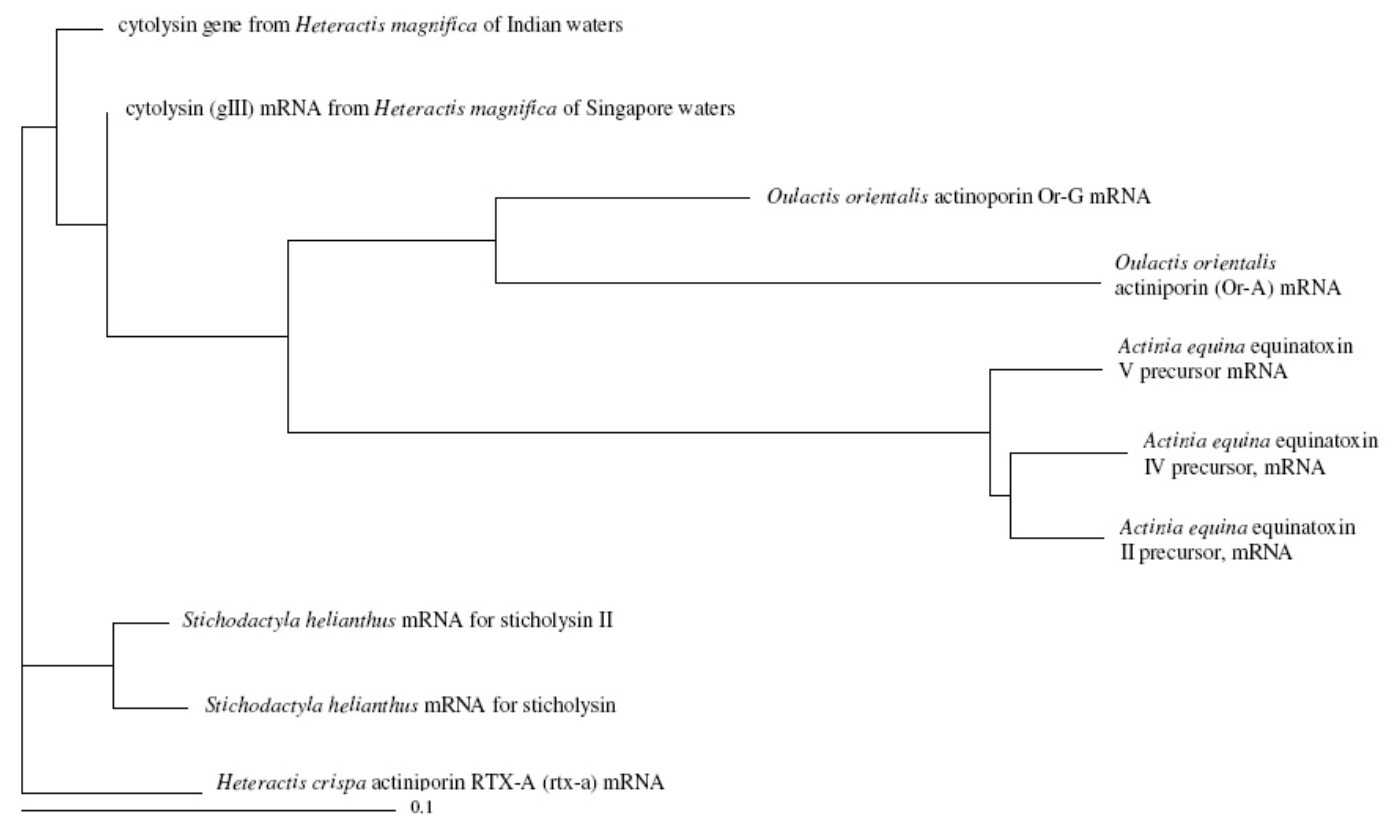

Figure 10. Phylogenetic analysis of the cytolysin gene of Heteractis magnifica with the other reported cytolysins from sea anemones. The $H$. magnifica cytolysin showed close relationship with sticholysin and actinoporin RTX-A, rather than equinatoxins.

\section{DISCUSSION}

The present study demonstrated the hemolytic activity of a cytolysin isolated from the sea anemone $H$. magnifica. The isolated toxin required alkaline $\mathrm{pH}(7$ to 9$)$ and a determined temperature $\left(25^{\circ} \mathrm{C}\right)$ for its optimal activity. Additionally, this study included cDNA amplification which enabled comparison of the conserved region of this cytolysin with others. 
The purified active protein from ion-exchange chromatography was separeted into two bands by SDS-PAGE, one with $\sim 14 \mathrm{kDa}$ and the other with $19 \mathrm{kDa}$. The nucleotide sequence of $H$. magnifica cytolysin was compared with the Hmg III cytolysin cDNA from the same species of Singaporean waters. Surprisingly, it showed variation in seven positions $(273,315,354,377,441,433$ and 456) of the cDNA bases together with corresponding differences in three amino acids (glutamine is replaced by lysine in $55^{\text {th }}$ position, arginine by threonine in $113^{\text {th }}$ position and asparagine by histidine in $132^{\text {nd }}$ position) in their deduced amino acid sequences.

The cytolysin sequence from the sea anemone $H$. magnifica was aligned with the reported cytolysins of other cnidarians. The multiple sequence alignment revealed that $H$. magnifica cytolysin shares more than $80 \%$ homology with the reported cytolysins from other sea anemones.

BLAST analysis of both this cytolysin and the cytolysin of the same Singaporean species revealed 97\% (Figure 8) nucleotide homology and 96\% homology with deduced protein sequence (Figure 9). Furthermore, it showed up to 95\% nucleotide homology with sticholysin II and $94 \%$ with sticholysin I from the sea anemone Stichodactyla helianthus and 94\% with actinoporin RTX-A from Heteractis crispa. Based on this homology study, a phylogenetic tree was constructed (Figure 10), which indicated a close genetic relationship among $H$. magnifica cytolysin, sticholysin and actinoporin RTX-A, rather than connection with equinatoxin.

In the present study, the cytolytic effect has been assessed using human erythrocytes. Interestingly, human serum possesses a total inhibitory effect on the cytolytic activity when added to the incubated erythrocytes. Further studies are necessary on the cytolytic effect of cnidarian cytolysins on other marine invertebrate, as the body fluid of the latter lacks RBC or molecules of human serum nature.

\section{REFERENCES}

1. Bernheimer AW. Cytolytic peptides of sea anemones. In: Hall S, Strichartz G, editors. Marine toxins: origin, structure and molecular pharmacology. Washington: American Chemical Society; 1990. p. 304-11.

2. Honma T, Shiomi K. Peptide toxins in sea anemones: structural and functional aspects. Mar Biotechnol (NY). 2006;8(1):1-10.

3. Macek P, Lebez D. Isolation and characterization of three lethal and haemolytic toxins from the sea anemone Actina equina L. Toxicon. 1988;26(5):441-51. 
4. Sencic L, Macek P. New method for isolation of venom from sea anemone Actina cari. Purification and characterization of cytolytic toxins. Comp Biochem Physiol. 1990;97(4):687-93.

5. Anderluh G, Macek P. Cytolytic peptide and protein toxins from sea anemones (Anthozoa: Actiniaria). Toxicon. 2002;40(2):111-24.

6. Macek P. Polypeptide cytolytic toxins from sea anemones (Actiniaria). FEMS Microbiol Immunol. 1992;5(1-3):121-9.

7. Anderluh G, Pungercar J, Strukelj B, Macek P, Gubensek F. The coding region of the equinatoxin II gene lacks introns. Croat Chem Acta. 1995;68(3):533-42.

8. Anderluh G, Pungercar J, Strukelj B, Macek P, Gubensek F. Cloning, sequencing and expression of equinatoxin II. Biochem Biophys Res Commun. 1996;220(2):43742 .

9. Anderluh G, Krizaj I, Strukelj B, Gubensek F, Macek P, Pungercar J. Equinatoxins, pore-forming proteins from the sea anemone Actinia equina, belong to a multigene family. Toxicon. 1999;37(10):1391-401.

10. Anderluh G, Barlic A, Podlesek Z, Macek P, Pungercar J, Gubensek F, et al. Cysteine-scanning mutagenesis of an eukaryotic pore-forming toxin from sea anemone: topology in lipid membranes. Eur J Biochem. 1999;263(1):128-36.

11. Anderluh G, Dalla Serra M, Viero G, Guella G, Macek P, Menestrina G. Pore formation by equinatoxin II, a eukaryotic protein toxin, occurs by induction of nonlamellar lipid structures. J Biol Chem. 2003;278(46):45216-23.

12. Kristan K, Podlesek Z, Hojnik V, Gutiérrez-Aguirre I, Guncar G, Turk D, et al. Pore formation by equinatoxin, a eukaryotic pore-forming toxin, requires a flexible $\mathrm{N}$ terminal region and a stable $\beta$-sandwich. J Biol Chem. 2004;279(1):46509-17.

13. Pungercar J, Anderluh G, Macek P, Gubensek F, Strukelj B. Sequence analysis of the cDNA encoding the precursor of equinatoxin $\mathrm{V}$, a newly discovered hemolysin from the sea anemone Actina equina. Biochim Biophys Acta. 1997;1341(1):105-7.

14. Wang Y, Chua KL, Khoo HE. A new cytolysin from the sea anemone, Heteractis magnifica: isolation, cDNA cloning and functional expression. Biochim Biophys Acta. 2000;1478(1):9-18.

15. Wang Y, Yap LL, Chua KL, Khoo HE. A multigene family of Heteractis magnifica lysins (HMgs). Toxicon. 2008;51(8):1374-82. 
16. Mebs D, Claus I, Schroter A, Takeya H, Iwanaga S. In: Gopalakrishnakone P, Tan CK, editors. Recent advances in toxinology research. Singapore: National University of Singapore; 1992. p. 392-5. 2 vol.

17. Mebs D. Anemonefish symbiosis: vulnerability and resistance of fish to the toxin of the sea anemone. Toxicon. 1994;32(9):1059-68.

18. Khoo KS, Kam WK, Khoo HE, Gopalakrishnakone P, Chung MC. Purification and partial characterization of two cytolysins from a tropical sea anemone, Heteractis magnifica. Toxicon. 1993;31(12):1567-79.

19. Belmonte G, Menestrina G, Pederzolli C, Krizaj I, Gubensek F, Turk T, et al. Primary and secondary structure of a pore-forming toxin from the sea anemone, Actinia equina $\mathrm{L}$. and its association with lipid vesicles. Biochim Biophys Acta. 1994;1192(2):197-204.

20. Simpson RJ, Reid GE, Moritz RL, Morton C, Norton RS. Complete amino acid sequence of tenebrosin- $C$, a cardiac stimulatory and haemolytic protein from the sea anemone Actinia tenebrosa. Eur J Biochem. 1990;190(2):319-28.

21. Blumenthal KM, Kem WR. Primary structure of Stoichactis helianthus cytolysin III. J Biol Chem. 1983;258(1):5575-81.

22. Fautin DG, Allen GR. Field guide to anemonefishes and their host sea anemones. Perth, WA: Western Australian Museum; 1992. 160 p.

23. Lowry OH, Rosebrough NJ, Farr AL, Randall RJ. Protein measurement with the folin phenol reagent. J Biol Chem. 1951;193(1):265-75.

24. Macek P, Malovrh P, Barlic A, Podlesek Z, Menestrina G, Anderluh G. Structurefunction studies of tryptophan mutants of equinatoxin II, a sea anemone pore-forming protein. Biochem J. 2000;346(Pt 1):223-32.

25. Bollag DM, Rozycki MD, Edelstein SJ. Protein methods. $2^{\text {nd }}$ ed. New York: John Wiley \& Sons Inc; 1996.

26. Laemmli UK. Cleavage of structural proteins during the assembly of the head of bacteriophage T4. Nature. 1970;227(5259):680-5. 